A World of Collaboration in Sports Medicine: the 2020 American Medical Society for Sports Medicine issue

\author{
Stephen Paul 이, ${ }^{1}$ Alex Benjamin Diamond, ${ }^{2}$ Jonathan A Drezner
}

With this issue, we celebrate the important collaboration between the American Medical Society for Sports Medicine (AMSSM), BJSM and sports and exercise medicine colleagues around the world. We also are excited to promote and preview the upcoming AMSSM annual meeting in Atlanta on 24-29 April 2020, 'A World of Collaboration in Sports Medicine'. As the rigor of peer review and demand for the highest quality research continues for eligible content in BJSM, we are thankful for the number of article submissions from AMSSM members. We encourage our members to continue to raise the level of their research to advance our discipline and match the high BJSM standard for future consideration.

\section{HIGHLIGHTS IN THIS ISSUE}

This issue features two AMSSM position statements. The first, an update from the original paper from the 1990s, reviews bloodborne pathogens in the context of sport participation by Dr Chris McGrew and colleagues (See page 200). This statement expands the list of bloodborne pathogens and more importantly updates information for the sport medicine practitioner and participant on transmission, effect on exercise and the current role of education to prevent transmission.

AMSSM past-presidents Dr Cindy Chang and Dr Margot Putukian also led an AMSSM position statement on Mental Health Issues and Psychological Factors in Athletes: Detection, Management, Effect on Performance and Prevention (See page 216). This paper provides a comprehensive, evidence-based update on mental healthcare for athletes. This statement examines psychological factors in athletes including personality issues and the psychological response to injury and illness and reviews the athletic culture and

\footnotetext{
${ }^{1}$ Department of Family and Community Medicine, University of Arizona, Tucson, Arizona, USA ${ }^{2}$ Orthopaedics, Vanderbilt University Medical Center, Nashville, Tennessee, USA

${ }^{3}$ Stadium Sports Medicine Center, University of Washington, Seattle, Washington, USA
}

Correspondence to Dr Stephen Paul, Department of Family and Community Medicine, University of Arizona, Tucson, Arizona, USA; spaulaz@mac.com environmental factors that impact mental health, including sexuality and gender issues, hazing, bullying, sexual misconduct and transition from sport. An Executive Summary including level of evidence using Strength of Recommendation Taxonomy is also highlighted in this issue (See page 216).

An important Interassociation statement supported by the National Collegiate Athletic Association on recommendations to prevent catastrophic injury and death in collegiate athletes is also included in this issue (See page 208). This consensus statement discusses independent medical care for student-athletes, the diagnosis and management of concussion and recommendations regarding year round practice for American football collegiate athletes.

One of three original works in this edition analyses the cost and diagnostic conditions of the preparticipation evaluation (PPE) programme in Italy (See page 231). Over $90 \%$ of tested athletes were cleared on first-pass evaluations. The AMSSM annual meeting will have a session reviewing updates on the PPE. Several AMSSM members played a critical role in the 5 th version of the PPE Monograph released in 2019. In an editorial, Dr Jonathan Drezner reports on highlights from the International Criteria for ECG interpretation in athletes and also outlines differences from the Seattle Criteria (See page 197). Of note, implementation of the newer criteria demonstrates improved specificity without loss of sensitivity for pathological conditions detected by ECG related to sudden cardiac death.

An original study from colleagues in Australia also will be of high interest. Denoted as TIPS, Team Illness Prevention Strategy, this study showed a reduction in illnesses in athletes competing in the Super Rugby Tournament (See page 245). We include two Infographics on athlete health as well. One complements the TIPS programme highlighting eight key steps to prevent infectious illness during championship competition (See page 251). The other Infographic explores the intestinal microbiome: significance, influences and effects on athletic health and performance (See page 250).
The third original investigation is a cohort study from Spain which demonstrates that even half the recommended amount of physical activity reduces cardiovascular risk factors compared with inactive individuals (See page 238). This study complements an editorial by Dr Irfan Asif and Dr Drezner on a call to action for incorporating exercise medicine as part of the curriculum and training within US medical education and sports medicine fellowships (See page 195). At the AMSSM annual meeting in Atlanta, a global perspective on exercise, workload and performance will be highlighted.

Last, Dr Stephanie Kliethermes and colleagues present a systematic review resulting from the summit on Youth Early Sport Specialization held at last year's AMSSM annual meeting (See page 221). In addition to identifying research gaps, they noted that early specialisation in youth sport does not appear to improve task-related performance outcomes during childhood and adolescence. An editorial led by Dr Neeru Jayanthi provides a historical perspective and addresses the need for a modern-day definition of sport specialisation (See page 196).

\section{AMSSM ANNUAL MEETING IN ATLANTA} ON 24-29 APRIL 2020 AND BEYOND

Additional areas to be highlighted at the AMSSM annual meeting in Atlanta further recognise the importance of collaboration within the world of sports medicine. AMSSM is proud to host the first international research session (more information at: https://www.amssm.org/ IntlResearchSubmissions.php). There will be an international forum on societal, medical and cultural challenges in sport. Exciting new approaches to the interdisciplinary care of the female athlete are planned. Other sessions will highlight the use of orthobiologics, the importance of leadership and collaboration in sports medicine, the throwing athlete, and using informatics collaboratively in sports medicine.

Finally, findings and recommendations from the AMSSM Task Force on Sexual Violence in Athletes will be presented. We as healthcare providers in sports medicine have a unique obligation to the health, safety and wellbeing of our athletes and patients. Now, more than ever, priority is being placed on protecting athletes from abuse at all levels of participation. A discussion piece in this edition addresses the disparity and lack of protection for athletes reporting abuse (See page 253). This important 


\section{Warm up}

editorial by Dr Victoria Roberts discusses ways to protect athletes by promoting a change in attitude towards sport while also still striving for success. We must address the disparity and lack of protection for athletes reporting abuse and foster meaningful change and safeguards for all of the athletes we serve.

We are grateful for the opportunity to compile an issue that draws attention to multiple aspects of a healthy population: encouraging exercise, screening for illness and disease, preventing illness, attending to the mental well-being of our athletes and ensuring a safe environment to train and compete. See you in Atlanta! Thank you.

Twitter Jonathan A Drezner @DreznerJon

Competing interests None declared.

Patient consent for publication Not required.

Provenance and peer review Commissioned; internally peer reviewed.

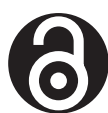

\section{OPEN ACCESS}

Open access This is an open access article distributed in accordance with the Creative Commons Attribution Non Commercial (CC BY-NC 4.0) license, which permits others to distribute, remix, adapt, build upon this work non-commercially, and license their derivative works on different terms, provided the original work is properly cited, appropriate credit is given, any changes made indicated, and the use is non-commercial. See: http:// creativecommons.org/licenses/by-nc/4.0/.

(C) Author(s) (or their employer(s)) 2020. Re-use permitted under CC BY-NC. No commercial re-use. See rights and permissions. Published by BMJ.

D Check for updates

To cite Paul S, Diamond AB, Drezner JA. Br J Sports Med 2020;54:193-194.

Accepted 15 November 2019

Br J Sports Med 2020;54:193-194. doi:10.1136/bjsports-2019-101781

\section{ORCID iDs}

Stephen Paul http://orcid.org/0000-0002-1005-5414 Jonathan A Drezner http://orcid.org/0000-0003-35199120 